YEARBOOK

of ANTITRUST

and REGULATORY

STUDIES

www.yars.wz.uw.edu.pl
Peer-reviewed scientific periodical, focusing on legal and economic issues of antitrust and regulation. Creative Commons Attribution-No Derivative Works 3.0 Poland License.

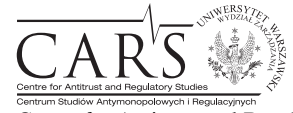

Centre for Antitrust and Regulatory Studies, University of Warsaw, Faculty of Management www.cars.wZ.uw.edu.pl

\title{
Directive on Antitrust Damages Actions and Current Changes of Slovak Competition and Civil Law
}

\author{
by
}

Ondrej Blažo*

\section{CONTENTS}

I. Introduction

II. Protection of leniency applicants and participants in settlement procedures

1. Position of the leniency programme and the settlement procedure in the Slovak legal order

2. Protection of leniency and settlement documents in the APEC

3. Actions for Damages and Access to Leniency and Settlement Documents

III. Disclosure of Evidence and Slovak Civil Court Proceedings

IV. Joint and several liability

V. Collective redress

VI. Limitation periods

VII. Effect of NCAs' decisions

VIII. Conclusions. Transposition of the Damages Directive into the Slovak legal order

\section{Abstract}

Slovak competition law enforcement can be characterized by infrequency of leniency applications and near absence of private enforcement. As a result, the adoption of the Damages Directive is not likely to cause substantial breakthrough in Slovakia, be it with respect to the rate of leniency applications or in private enforcement. A comprehensive amendment of Slovak competition law took place in 2014. Changes introduced therein reflected, among other things, the practice

* Comenius University in Bratislava, Faculty of Law, Institute of European Law; e-mail: ondrej.blazo@flaw.uniba.sk. The paper was prepared within the grant project APVV-0158-12 "Efektívnosṫ právnej úpravy ochrany hospodárskej sútaže v kontexte jej aplikácie v praxi”. 
of the European Commission regarding access to its file. A new approach was also introduced towards damages claims submitted against leniency applicants. The paper will first consider the question whether it is necessary to further redesign these new Slovak rules because of the adoption of the Damages Directive, or if they have been successfully pre-harmonized. Along with changes to Slovak competition law, procedural rules for civil courts were also re-codified. Hence the second part of this analysis will focus on the question if a new civil procedure framework, including obligatory harmonization, could foster private enforcement of competition law. Summarizing the resulting answers, the third question focuses on who could benefit from further changes to Slovak legislation - final consumers or enterprises that are involved in the production chain. Finally, will changes in Slovak legislation driven by the Directive be coherent with its overall legal system, or will they appear to be an odd and peculiar piece of legislation?

\section{Résumé}

Le droit slovaque de la concurrence peut être caractérisé par la rareté des demandes de clémence et par la quasi-absence de l'application privée du droit de la concurrence. En conséquence, l'adoption de la Directive relative aux actions en dommages n'est pas susceptibles de causer percée importante en Slovaquie, quoi que ce soit le taux des demandes de clémence ou l'application privée du droit de la concurrence. La reforme complexe du droit de la concurrence slovaque a eu lieu en 2014. Les changements introduits par cette réforme ont pris en compte, entre autres, la pratique de la Commission européenne concernant l'accès aux documents figurants dans ses dossiers. Une nouvelle approche a également été introduite vers les actions en dommages concernant les demandeurs de clémence. Cet article examinera d'abord la question si il est nécessaire de remanier ces nouvelles règles slovaques en raison de l'adoption de la Directive, ou si elles ont été déjà préharmonisé. Outre les modifications apportées à la loi slovaque de la concurrence, la reforme mentionnée ci-dessus a ré-codifié les règles de procédure civile. En conséquence, la deuxième partie de cette analyse se concentrera sur la question si un nouveau cadre de la procédure civile, y compris l'harmonisation obligatoire, pourrait contribuer à encourager le développement de l'application privée du droit de la concurrence. En résumant les réponses données, la troisième question porte sur qui pourraient bénéficier des changements à la législation slovaque consommateurs finaux ou des entreprises impliquées dans la chaîne de production. Enfin, l'article va tenter de répondre si les changements dans la législation slovaque entraînés par la Directive seront cohérent avec le système juridique, ou vont-ils plutôt être une pièce étrange et particulière de la législation?

Key words: competition law; Directive 2014/104/EU; Slovakia; civil law; commercial law; reform of competition law; leniency programme; settlement; procedural law.

JEL: K23; K42. 


\section{Introduction}

In its opinion in the Pfleiderer case, Advocate General Mazák presented his thoughts regarding the position of private enforcement of competition law. He said, 'I consider that Regulation No 1/2003 and the case-law of the Court have not established any de jure hierarchy or order of priority between public enforcement of EU competition law and private actions for damages. While no de jure hierarchy has been established, at present the role of the Commission and national competition authorities is, in my view, of far greater importance than private actions for damages in ensuring compliance with Articles 101 and 102 TFEU. Indeed so reduced is the current role of private actions for damages in that regard that I would hesitate in overly using the term "private enforcement".' All disputes concerning private antitrust enforcement seemed to have been ultimately reduced to the relation between the effectiveness of leniency programmes and access to the files held by competition authorities by antitrust victims (in order to support their damages claims in civil court proceeding) and other forms of preferential approach given to leniency applicants in civil ${ }^{2}$ damages actions. Even the long-awaited Damages Directive, which was finally adopted in 2014, dedicated its entire Chapter II to access to the file in order to protect the interests of leniency applicants.

The procedural sphere of Slovak competition legislation (Act No. 136/2001 Coll. on protection of economic competition and amending act of the Slovak National Council No 347/1990 Coll. on organization of ministries of other central bodies of state administration of the Slovak Republic as amended, hereafter, APEC) has recently been subject to significant changes. Private enforcement, protection of leniency applicants and the settlement procedure were all part of an extensive Amendment introduced in 2014 (hereafter, Amendment 2014). Moreover, a new Civil Dispute Code (Act No 160/2015 Coll., hereafter, CDC) was adopted by the Parliament in May 2015. The latter will replace, with effects from 2016, the current Civil Court Procedure Code of 1963 (Act No. 99/1963 Coll., hereafter, CCPC) that has been amended more than eighty-times since its introduction. In light of the above, the first question to be considered in this paper is: do these recent modernization amendments go in line with Directive 2014/104/EU of the European Parliament and of the Council of 26 November 2014 on certain rules governing actions for damages under national law for infringements of the competition law provisions of the

\footnotetext{
1 Opinion of Advocate General Mazák delivered on 16 December 2010, Case C-360/09 Pfleiderer $A G$ v. Bundeskartellamt.

2 The Slovakia civil law system is broadly divided into two subsystems: civil law in the narrower sense of the word and commercial law.
} 
Member States and of the European Union ${ }^{3}$ (hereafter, Damages Directive). Moreover, harmonization by way of the Damages Directive is limited to 'certain rules' only and so a further question to be addressed here is if these 'certain rules' are in fact compatible with the Slovak legal order and if, together with 'non-harmonized' national civil rules, they make a adequate legal framework for sufficient private enforcement of competition law in Slovakia.

The paper will focus on a number of selected elements of damages claims for harm caused by competition infringements in the Slovak legal order vis$a$-vis the EU 'private enforcement package' (the Damages Directive and the soft law of the Commission dealing with private antitrust enforcement). These include: the position of leniency programme and the settlement procedure in the overall legal system, joint and several liability, the passing-on defence, limitation periods, and effects of decisions issue by national competition authorities (hereafter, NCAs).

\section{Protection of leniency applicants and participants in settlement procedures}

\section{Position of the leniency programme and the settlement procedure in the Slovak legal order}

The European Commission (hereafter, EC or Commission) always declares its cautiousness when it comes to the protection of the interests and legal certainty of leniency applicants as well as the predictability of its leniency programme as a whole. Yet the EC never actually introduced any legally binding provisions regarding its leniency programme. In comparison to the benefits associated with a settlement (part of the EC's procedural rules laid down in a Regulation ${ }^{4}$ ), the basis of EU leniency is still only contained in a Commission notice - a non-binding soft law act ${ }^{5}$.

Still, the Slovak legislator, inspired by the EC Leniency Notice, introduced conditions for immunity from fines and fine reductions directly into the

3 OJ L 349, 05.12.2014, p. 1-19.

${ }^{4}$ Commission Regulation (EC) No. 773/2004 of 7 April 2004 relating to the conduct of proceedings by the Commission pursuant to Articles 81 and 82 of the EC Treaty (OJ L 123, 27.04.2004, p. 18) as amended by Commission Regulation (EC) No. 622/2008 of 30 June 2008 amending Regulation (EC) No. 773/2004, as regards the conduct of settlement procedures in cartel cases (OJ L 171, 01.07.2008, p. 3).

5 Commission Notice on immunity from fines and reduction of fines in cartel cases (OJ C 298, 08.12.2006, p. 17). 
APEC in 2004 (Article 38 APEC). Certain specific issues regarding leniency applications, as well as markers, summary applications and hypothetical applications, were further explained in a soft law document issued by the Antimonopoly Office of the Slovak Republic (hereafter, AMO or NCA) in $2004^{6}$. Amendment 2014 made leniency provisions more visible in the APEC (Article 38d received the title: 'Leniency Programme') as well as increased their precision. Furthermore, rules on leniency applications, their form and requirements, markers, summary applications, hypothetical applications were all made binding by a new decree of the $\mathrm{AMO}^{7}$. Hence the Slovak leniency programme has become more predictable lately - it now provides leniency applicants with a higher degree of legal certainty because it is fully regulated by 'hard law'.

Similarly, before Amendment 2014, the Slovak settlement procedure was set out in 'soft law' guidelines of the AMO only ${ }^{8}$. Amendment 2014 introduced the settlement procedure directly into the APEC (Article 38e APEC); some of its procedural details as well as the percentage of the available fine reduction are regulated by a new decree of the $\mathrm{AMO}^{9}$.

Fully regulating the national leniency programme and settlement procedure by binding legal instruments is an important step towards their protection in court proceedings, as required by the Damages Directive. It would be quite difficult to provide protection to given procedural instruments and their corresponding documentation, as well as undertakings involved in respective procedures, if there was no actual legal basis for such procedures. In other words, it would be difficult to protect them if they were guided merely by the 'soft laws' of an administrative body - the AMO.

\section{Protection of leniency and settlement documents in the APEC}

Amendment 2014 completely re-designed Slovak provisions on access to the file in competition proceedings, especially those based on the use of the leniency programme.

${ }^{6}$ Non-imposing or reducing a fine in some types of agreements restricting competition pursuant to the Article 38 para. 11 and 12 of the Act (leniency program) http://old.antimon. gov.sk/files/30/2009/Leniency5(k)-en.rtf (accessed 20.10.2015).

${ }^{7}$ Decree of the Antimonopoly Office of the Slovak Republic No. 172/2014 Coll. laying down details on leniency programme of 19 June 2014.

8 Conditions for the application of settlement procedure available at: http://old.antimon.gov. sk/files/26/2012/Conditions $\% 20$ for $\% 20$ the $\% 20$ application $\% 20$ of $\% 20$ settlement $\% 20$ procedure. rtf (accessed 20.10.2015).

9 Decree of the Antimonopoly Office of the Slovak Republic No. 171/2014 Coll. laying down details on settlement of 19 June 2014. 
First, Amendment 2014 introduced a definition of 'confidential information'. The latter was defined in Article 40(5) APEC as information which is neither a trade secret, nor information protected pursuant to special legislation (such as classified information, bank, telecommunication, tax or post secrets), and which is available only to the restricted group of persons and its disclosure would significantly harm the legally protected interest of person which has provided it or other person'. Information submitted by the applicant within the leniency programme, if disclosing it could endanger the application of the procedure pursuant to Article 38d APEC, is explicitly deemed to fall within the category of 'confidential information'. Parts of a leniency application can obviously contain trade secrets, triggering the application of the specific rules of the protection of trade secrets. Although this is not explicitly stated by the provision of Article 40(5), it is clear that settlement statements will also fulfil the criteria of 'confidential information'.

Second, leniency applications themselves are protected under Article 40(3) APEC. A leniency application, as well as other documents and information which have been provided in connection with a leniency application, are not part of the file. As such, they are excluded from access to the file until the issuance by the AMO of a Statement that precedes the rendering of a decision under Article 33 APEC (a similar act to the EC's Statement of Objections).

In general, confidential information, classified information, bank secrets, tax secrets, trade secrets, telecommunication secrets, and post secrets are excluded from access to the file. However, Amendment 2014 evolved a specific regime for granting access to those parts of the file that contain trade secrets or confidential information in case these documents contain evidence of an antitrust infringement and are necessary for defending against such charges ${ }^{10}$. Since this specific access to the file regime is relevant for procedural parties only, it cannot be requested by other persons, particularly within private enforcement.

\section{Actions for damages and access to leniency and settlement documents}

Alongside procedural parties which have the right to access the file ex lege under Article 40(1) APEC, access to the file can also be granted to all other persons that prove the legitimacy of their request. It is probable that persons that suffered harm from an antitrust infringement will be granted such access. Hence, procedural parties have the right to access the file ex lege, and the

${ }^{10}$ Cf. Art. 40(8)-(10) APEC. 
possibility of access to the file by other persons depends on the assessment and decision of the AMO.

If access is granted, those that benefited from it have full access to the entire file apart from those of its parts which contain: confidential information, classified information, bank secrets, tax secrets, trade secrets, telecommunication secrets, and post secrets. Regarding those parts of the documents that contain trade secrets or confidential information, persons granted access to the file have only access to their summaries or general descriptions. In practice therefore, a person who suffered harm from an anticompetitive behaviour and was granted access to the file by the AMO may look at a document containing a leniency application or settlement statement. However, he will likely only see a redacted/shortened version of such documents (where relevant parts are blanked or replaced by a general summary or description that contains no details). Even the need to prepare an action for damages due to harm caused by an antitrust infringement does not change the extent of the rights of such person.

\section{Disclosure of evidence and Slovak civil court proceedings}

The Slovak legal order does not provide for a possibility to seek a court order before starting civil proceedings which would be meant to facilitate a civil action. The court can be asked to order the securing of evidence only if there is concern that a given piece of evidence will not be available in the future, or will be produced only with serious difficulties. Such request can be submitted even before filling an action by the plaintiff ${ }^{11}$.

Although during court proceedings the court or the judge can order anybody to produce a document that may be used as evidence ${ }^{12}$, due to the contradictory character of civil proceedings, the court or the judge will issue such order only if such evidence is mentioned or described by one of the parties of the civil proceedings. The duty to produce a document in one's possession is a general obligation and covers all subjects of law, including parties to the court proceedings, state authorities and $3^{\text {rd }}$ persons. There is no limitation of such request in Slovakia, unlike required in the Damages Directive. Hence, it will be necessary to transpose this limitation as a specific rule for ordering the provision of a document. On the other hand, the possible sanction for refusing to provide a documents is quite low (currently up to $820 €$, or up to

\footnotetext{
11 Cf. Art. 78 CCPC, Art. 338 CDC.

12 Cf. Art. 129(2) CCPC, Art. 185 CDC.
} 
$1640 €$ in case of a repeat offence ${ }^{13}$ - after the forthcoming re-codification it will be up to $500 €$ for a single and $2000 €$ for repeat offences ${ }^{14}$ ). The fine is low when compared to the possible level of damages in antitrust cases. It is thus unlikely that a defendant will be willing to produce such document, even if risking a court fine. Clearly, this fine is neither effective, nor proportionate, nor dissuasive as required by the Damages Directive (Article 8 para 2) in cases of high amounts of damages claimed. On the other hand, the Damages Directive orders (or suggests ${ }^{15}$ ) other alternative penalties: 'the possibility to draw adverse inferences, such as presuming the relevant issue to be proven or dismissing claims and defences in whole or in part, and the possibility to order the payment of costs.' The new CDC strengthens the contradictory character of civil court proceedings whereby the party that is not able to prove its factual statement with evidence loses the case.

The formulation of possible penalties for non-compliance with a court order to provide evidence in favour of the counter-party seems, therefore, to modify the contradictory character of civil proceedings. After the transposition of that rule into the Slovak legal order, it will thus appear quite out of place. The position of the defendant can became peculiar: in some cases, due to a court order, the defendant will either provide the requested evidence against himself, or he will lose the case completely. Although not all principles of criminal proceedings apply strictly in civil litigation, breaking the principle of nemo tenetur in civil litigation can appear problematic since the very same evidence can be used in criminal proceedings (since abuses are a crime in Slovakia). However, admittedly, some crucial documents that could be helpful for plaintiffs are excluded from court disclosure orders (leniency applications or settlement statements). Yet the actual text of the prohibited agreement, if written down, is not excluded. Nevertheless, the following situation can also appear: a plaintiff is seeking an order requesting the submission of non-specific evidence, or evidence the existence of which is uncertain at the time of the court order. Furthermore, if there is a sanction whereby the facts claimed by the victim are considered proven if the defendant fails to provide the requested evidence, the plaintiff will easily be able to create a rebuttable presumption of claimed facts. Still, it will be ultimately irrelevant whether the defendant refuses to provide the requested evidence supporting the claim of the plaintiff, or if the defendant simply does not have such document or piece of evidence.

13 Art. 53 CCPC.

14 Art. 98 CDC.

15 The wording of this provision is unclear throughout different language versions: some formulate it as an order to the Member State ('shall include' for instance in respective English, Czech, Italian, Spanish versions) or a suggestion to the Member States ('should include' or 'can include' respectively in the Slovak and German version). 
So Chapter II of the Damages Directive entitled 'Disclosure of Evidence' shall be transposed into the Slovak legal order by completely new, tailor-made rules because current national legislation does not provide such approach to court disclosure orders and corresponding sanctions on the one hand, and the protection of some classes of documents on the other. However, it will be necessary to establish measures against abuses by plaintiffs.

\section{Joint and several liability}

Basic rules of liability for damage caused by an infringement are contained in Article 373 et seq. of the Commercial Code ${ }^{16}$, irrespective of the fact if the injured party is an undertaking or not. When compared to the rules on damages liability under the Civil Code (general system), liability under the Commercial Code is based on principles of strict liability. Under Article 379 of the Commercial Code, an injured party has the right to compensation for actual loss and the loss of profit. This compensation is limited to loss that was anticipated by the infringer as a possible outcome of his illegal activity, or could be expected due to circumstances that the infringer was aware of or should have been aware of. Although the requirement to pay interest in order to compensate harm can be understood either as a form of additional compensation for the loss of profit or the payment of punitive interests for a delayed payment ${ }^{17}$, the limitation of damages to expected harm only can be considered contrary to the Damages Directive. It is also a procedural obstacle to effective claims since it can be an additional issue to be resolved during court proceedings.Article 383 of the Commercial Code clearly defines the principles of joint and several liability. This principle of the Damages Directive is thus coherent with the Slovak legal order and does not require further adjustments.

Amendment 2014 introduced a specific regime and a modification of joint and several liability regarding leniency applicants whereby:

- party to a competition restricting agreement, which fulfilled the conditions for the participation in the leniency programme, is not obliged to pay damages if the damages could be paid by other parties to the same competition restricting agreement;

\footnotetext{
16 Act No. 513/1991 Coll. Commercial Code as amended of 5 November 1991.

17 The content and extent of this type of compensation is not sufficiently described in the Damages Directive, and can cause problems during transposition, since it can be understood in different ways, as it was suggested above.
} 
- party to a competition restricting agreement, which fulfilled the conditions for the participation in the leniency programme, is excluded from the obligation to settle with those of the other participants to the same competition restricting agreement which paid damages;

- if the damage cannot be paid by other participants to the same competition restricting agreement, the party which fulfilled the conditions for the participation in the leniency programme is liable only for damages caused to its own direct or indirect customers or suppliers ${ }^{18}$.

What must be noted first is that this provision covers only those successful leniency applicants that gained full immunity under the leniency programme established by the Slovak AMO (under Article 38d APEC). Thus this special regime does not, therefore, cover successful leniency applicants that were granted immunity from fines by the Commission.

Second, the Slovak legal order does not contain a special regime for joint and several liability in cases involving small and medium enterprises (hereafter, SMEs). Importantly, the definition of SMEs is based on EU-wide criteria and in small economies such as Slovakia, the majority of its companies will fall into this category.

Third, even if Slovakia introduced a special regime for successful leniency applicants, this does not correspond with Article 11(4)\&(5) of the Damages Directive. The Slovak regime is much more 'lenient' to successful applicants while still providing the victims with the possibility of full compensation. The basic principle in Slovakia is that an immunity recipient is excluded from a compensation scheme, provided that such compensation by other members of the cartel is sufficient.

Hence due to the requirements of the Damages Directive, it is clear that Slovakia is obliged to change its provisions dealing with limited liability for damages of immunity recipients. This change will remove one of the features that could strengthen the attractiveness of the Slovak leniency programme and thus improve the effectiveness of competition enforcement overall.

Regarding the attribution of civil liability and the possible success of a claim, the question of the 'passing-on defence' must be mentioned. Slovak civil law does not have a similar provision at the moment so the legal institution of a 'passing-on defence' shall be designed as a brand new feature of the Slovak legal order. There are two ways how this institution can be understood: (1) it can be considered a limitation of liability of undertakings that infringed competition rules; or (2) it can constitute a form of procedural defence. Forcing the introduction of a 'passing-on defence' into national legal orders is a strong interference with domestic civil law regimes of individual Member

18 Cf. Art. 42 APEC. 
States. While it is not as interesting to consider how this institution will by transposed into national legislation (it is probable that the text of the Damages Directive will be copied only), its application in practice will be far more interesting.

\section{Collective redress}

Individual claims against undertakings that infringed competition rules can be effective in cases when the injured party has sufficient resources and legal support to prove such claims. The need to submit a well-prepared action, supported by sufficient evidence, will become even more evident in Slovakia under the new CDC. According to its new procedural rules, Slovakian courts are not obliged to find the 'objective truth' (real state of matters) but only to decide which 'truth' of the parties can be considered proven. Hence a party can lose merely because it is not able to produce enough evidence in time. Individual claims for damages arising from antitrust infringements can thus be effectively enforced mainly in disputes between undertakings - they seem to be less effective in cases affecting final customers. An effective collective redress system can overweight economic power and the legal resources at the disposal of the offending undertaking. Unfortunately, the EU did not dare to require Member States to introduce a collective redress system in antitrust matters in the Damages Directive. The whole system of the Directive is more focused on addressing undertaking-undertaking claims than customerundertaking disputes. This realisation is illustrated by the Directive's specific, and elaborate provisions on the 'passing-on defence' on the one hand, with almost no provisions facilitating customers claims on the other.

Neither the current CCPC nor the newly adopted CDC contain provisions on collective redress that can be employed in order to recover damages in competition matters. Since the Damages Directive does not impose a duty upon the Member States to introduce a collective redress system in competition matters, it is unlikely that Slovakia will enact such system any time soon.

Yet some authors ${ }^{19}$ see certain features of opt-in actions in Slovakia's general procedural rules - it is currently possible to file a joint action by several plaintiffs, or the court can join several cases into one joined case, in order to achieve procedural economy. These actions remain, however, still separate and individual claims that must be individually assessed by the court,

19 For instance: S. Šramelová, 'Kolektívne žaloby pri súkromnoprávnom vymáhaní sútažného práva' ['Collective Actions in Private Enforcement of Competition Law'] (2010) II Notitiae ex Academia Bratislavensi Iurisprudentiae 107-114. 
even though this can be done by a single judgment with multiple operative parts. As Professor Bejček warns ${ }^{20}$, the majority of claimants will not be willing to push through their relatively small claims, and thus infringers will not fear substantial claims for damages if the total damage consists of a myriad of small individual harms caused to individual customers. Finally, consumer associations do not have standing in Slovak courts in damages claims unless they act as a proxy for certain individual consumers ${ }^{21}$.

\section{Limitation periods}

Slovakia's general rules of limitation periods for damages claims set by the Commercial Code will currently also apply to damages claims stemming from antitrust infringements. There is a general four-year limitation period that shall start running when an injured party gets to know, or can reasonably be expected to know, of the harm incurred and the identity of person liable for damages. This limitation period will expire no later than 10 years from the end of the injurious behaviour that caused the harm at stake ${ }^{22}$.

Aside from a similarity in the definition of when the time of the limitation period begins to run, the rules on limitation periods are different in the Damages Directive and Slovak commercial law. The required limitation period is longer in the Directive, which also does not provide for a final limitation period (for instance, after several suspensions or interruptions, it can run almost forever). Moreover, Slovak law does not consider at the moment an investigation by an administrative body to be a reason for the interruption or suspension of the limitation period. These new specific rules of the Damages Directive shall thus be transposed into Slovak civil rules.

Although Article 10(4) of the Damages Directive allows Member State to choose if they suspend or interrupt the limitation period, the results of such choices across Europe can undermine the harmonisation initiative of the damages claim system. An interruption of the limitation periods is less problematic - the limitation period will restart after a final infringement

20 J. Bejček, 'Vybrané ekonomické a právní aspekty náhrady škody v rámci soukromého 9vymáhání soutěžního práva' ['Selected Economic and Legal Aspects of Damages in Private Enforcement Actions'] [in:] Súkromnoprávne vymáhanie sútažného práva [Private Enforcement of the Competition Law], Bratislava 2010, p. 9 et seq.

21 Associations of consumers have standing in protection of 'collective interests of consumers' cases. However, only refraining from illegal behaviour and restitutio in integrum can be requested in such proceedings (Cf. Art. 54 of Commercial Code).

22 Art. 397 and 398 of the Commercial Code. 
decision. A suspension can be more problematic, however, since its term shall be calculated with reference to an 'action for the purpose of the investigation or its proceedings'. Yet the latter can be hard to establish in Slovakia because the AMO does not publish such information. Furthermore, the beginning of an investigation or proceedings is irrelevant, what is of importance is the 'action for the purpose of investigation/proceeding' which can precede the investigation or proceedings themselves. Still, interruptions and suspensions of the limitation period appear irrelevant in practice for follow-on actions where a plaintiff gets the knowledge of the infringement and the identity of the infringer from the infringement decision only.

\section{Effect of NCAs' decisions}

Under Article 135 CCPC (and Article 189 CDC), Slovak courts are bound by the decision of the responsible body finding that an administrative infringement has been committed and stating the identity of the infringer. Since the AMO adopts such decisions in competition matters, these provisions are in line with Article 9(1) of Damages Directive. On the other hand, although decisions issued by foreign NCAs are acceptable as evidence, the Slovak legal order does not have a legal instrument of 'prima facie evidence'. Furthermore, it is not clear from the wording of Article 9(2) of Damages Directive if the duty of a Member State is fulfilled by not prohibiting the use of such decisions as evidence, or if Member States are required to explicitly allow their courts to use such evidence or to explicitly order the courts to use such evidence as a 'prima facie evidence'.

\section{Conclusions. Transposition of the Damages Directive into the Slovak legal order}

It is clear that the transposition of the Damages Directive will require amendments of several Slovakian legal acts. These will include at least the APEC, the Commercial Code and the CCPC/CDC because some of their current provisions are not in line with the Damages Directive. Furthermore, it is necessary to introduce completely new rules on joint and several liability, its limitations regarding SMEs, as well as the 'passing-on defence'. Regarding access to the file and access to evidence, rules on joint and several liability, the passing-on defence, and limitation periods, Member States are left by the 
Damages Directive with little room to consider the extent and content of their national provisions. On the other hand, when the Directive does provide the Member States with a certain degree of discretion, its rules do not seem to be clear enough. This is so, for instance, with respect to possible sanctions for the failure to provide evidence or the estimation of the quantification of harm. There are two possible paths for the transposition of the Damages Directive: (1) amending at least all of the above-mentioned acts or, (2) enacting a new act designed to deal with damages claims stemming from antitrust infringements and repealing all existing provisions contrary to this act (Article 42 APEC). The first path will make transposition more consistent with the rest of the acts and regulations at stake, the second path is, however, far simpler from the legislative point of view.

Nevertheless, the Slovak legal order is currently containing provisions that are fostering some aspects of private antitrust enforcement or mitigating its possible conflict with public enforcement (Article 42 APEC). Yet private enforcement of competition law is still almost non-existent and changes introduced due to the transposition of the Damages Directive will hardly change this situation. These changes are partially technical, partially odd and incoherent with Slovak private law (as well as 'downgrade' the attractiveness of the Slovak leniency programme) and do not change the system as a whole. Without an effective collective redress system for final customers, private enforcement of competition law will remain solely in the "undertakingundertaking' sphere.

\section{Literature}

Bejček J., 'Vybrané ekonomické a právní aspekty náhrady škody v rámci soukromého vymáhání soutěžního práva' ['Selected Economic and Legal Aspects of Damages in Private Enforcement Actions'] [in:] Súkromnoprávne vymáhanie sútažného práva [Private Enforcement of the Competition Law], Bratislava 2010.

Janáč V., Kurilovská L., Hospodárska sútaž a jej ochrana v trestnom práve [Economic competition and its protection by criminal law], (2011) 3(94) Právny obzor.

Kalesná K., Blažo O., Zákon o ochrane hospodárskej sútaže. Komentár [Act on Protection of Economic Competition. Commentary], Praha 2012

Králičková B., Súkromnoprávne aspekty protimonopolného práva [Private-law enforcement of anti-monopoly law], Bratislava 2012.

Králik A., Náhrada škody spôsobenej porušením sútažného práva [Compensation of damage caused by infringement of competition law ], Bratislava 2014.

Šramelová S., 'Kolektívne žaloby pri súkromnoprávnom vymáhaní sútažného práva' ['Collective Actions in Private Enforcement of Competition Law'] (2010) II Notitiae ex Academia Bratislavensi Iurisprudentiae. 